\title{
Study of incidence and outcome of acute inversion of uterus
}

\author{
Vidyadhar B. Bangal ${ }^{1 *}$, Swati D. Gagare ${ }^{1}$, Samita Bhardwaj' ${ }^{2}$, Sonal Raut ${ }^{2}$
}

${ }^{1}$ Department of Obstetrics and Gynecology, Rural Medical College, Loni, Ahmednagar, Maharashtra, India

${ }^{2}$ IMHI, Jiv Daya Foundation, Dallas, USA

Received: 20 October 2018

Accepted: 13 November 2018

\section{*Correspondence:}

Dr. Vidyadhar B. Bangal,

E-mail: vbb217@rediffmail.com

Copyright: (c) the author(s), publisher and licensee Medip Academy. This is an open-access article distributed under the terms of the Creative Commons Attribution Non-Commercial License, which permits unrestricted non-commercial use, distribution, and reproduction in any medium, provided the original work is properly cited.

\section{ABSTRACT}

Background: Acute inversion of uterus also called as puerperal inversion of uterus is a rare, but life-threatening complication of third stage of labour. Severe uterine atony, mismanagement of third stage of labour, adherent placenta are some of the common factors associated with the occurrence of acute inversion of uterus. Early recognition and prompt treatment are important to save life of the woman.

Methods: A retrospective cross-sectional record-based study was carried out to find out the incidence, presentation and outcome of cases of acute inversion of uterus admitted to Pravara Rural Hospital Loni for a period of three years (October 2015 to September 2018).

Results: During the study period, there were 27,134 deliveries including 8,834 caesarean sections. There were six cases of acute inversion of uterus in the hospital during study period. The incidence of acute inversion of uterus was 0.22 per one thousand deliveries $(0.27$ per thousand vaginal deliveries and 0.11 per one thousand caesarean sections). Three cases were referred from outside hospital and three cases had delivered at Pravara Rural Hospital. Five cases had delivered vaginally, where as one case had undergone caesarean section. There were two maternal deaths and four survivals among six cases of inversion of uterus. Severe anaemia, irreversible hypovolemic shock and multi-organ failure were causes of maternal deaths.

Conclusions: Prompt recognition of uterine inversion and its immediate reposition under anaesthesia was a key for successful management. Delay in recognition and transfer of cases resulted in haemorrhagic and neurogenic shock, leading to death of a women. Institutional deliveries with practice of principles of active management of third stage of labour (AMTSL) and improvement in emergency obstetric care services at peripheral hospitals, avoiding delays at all levels will help to reduce the incidence, morbidity and mortality associated with acute inversion of uterus.

Keywords: Acute inversion of uterus, Maternal mortality, Postpartum haemorrhage, Third stage labour complications

\section{INTRODUCTION}

Uterine inversion is defined as the turning inside out of the fundus into the uterine cavity. Acute inversion is a rare but a serious obstetric emergency. Women can sink into profound shock which can prove fatal. Immediate management of shock and manual repositioning of the uterus both reduce morbidity and mortality. ${ }^{1}$ Baskett et al analysed data in a North American unit over 24 years and noted a four-fold decrease in the incidence of acute uterine inversion associated with vaginal birth after the introduction of active management of the third stage, from 1 in 2304 to 1 in $10044 .^{2}$ The perception amongst many obstetricians is that uterine inversion is very rare: it will occur only once in a decade in most British maternity units (approximately 1:27 902 births). ${ }^{3}$ Baskett et al, however, reported the incidence as 1:3737, which would suggest occurrence at least once a year in most units. ${ }^{2}$ It is well established that mismanagement of the third stage of labour (premature traction on umbilical cord and fundal 
pressure before separation of placenta) is the commonest cause of acute uterine inversion. This can happen when delivery is conducted by an untrained birth attendant, a situation more likely to occur in developing countries, which explains why the incidence in India is treble that of the UK. Many other risk factors have been mentioned, including uterine atony, fundal implantation of a morbidly adherent placenta, manual removal of the placenta, precipitate labour, a short umbilical cord, placenta praevia and connective tissue disorders. ${ }^{4-11}$ It must be understood, however, that, in up to $50 \%$ of cases, no risk factors are identified and there is no mismanagement of the third stage. This condition can, therefore, be unpredictable. ${ }^{12}$

\section{METHODS}

A retrospective cross-sectional study was carried out to find out the incidence and outcome of cases of acute inversion of uterus admitted to Pravara Rural Hospital, Loni, which is a 1250 bedded tertiary care teaching hospital located in rural area of central India. This multispecialty hospital gets referral of high-risk obstetric cases from neighboring villages and townships. Approximately 9000 deliveries take place per year in hospital. All cases of inversion of uterus that happened at Pravara Rural Hospital and the cases which were referred from outside during three-year period (October 2015-September 2018) were included in the study.

\section{Inclusion criteria}

- All cases of acute inversion of uterus,whether complete and incomplete variety.

- Inversion cases delivered at Pravara Rural Hospital or at any other place.

- Inversion cases following vaginal delivery or caesarean section.
- Inversion cases irrespective of parity.

- Inversion of uterus-Spontaneous or Iatrogenic.

- Inversion cases, whether they were treated or not treated outside the hospital.

\section{Exclusion criteria}

- Chronic inversion cases.

- Non-obstetric cases of inversion.

Data was collected from hospital records that included admission register, labour room register, operation theatre register, mortality register. All relevant information that include age of the patient, parity, place of delivery, type of delivery, type of birth attendant at the time of delivery, condition of patient at the time of admission, vital parameters like pulse rate, blood pressure, pallor, state of consciousness, degree of inversion, possible cause for inversion, haemoglobin level of patient, type of treatment given, need for blood transfusion, any surgical treatment, need for admission in intensive care unit, outcome of patient, duration of hospital stay was gathered in structured proforma.

Delivery data pertinent to duration of project was gathered from medical record section and labour room. Total number of deliveries, total number of caesarean sections, number of cases of acute inversion of uterus following vaginal and caesarean section were noted down. The incidence of inversion and outcome were calculated and expressed in percentages and ratios.

\section{RESULTS}

There were 27,134 deliveries including 8,834 caesarean sections during the study period. Six cases of acute inversion of uterus were admitted during study period (Table 1).

Table 1: Clinical case details.

\begin{tabular}{|c|c|c|c|c|c|c|c|c|}
\hline $\begin{array}{l}\text { Age } \\
\text { years }\end{array}$ & Parity & $\begin{array}{l}\text { Type of } \\
\text { delivery }\end{array}$ & $\begin{array}{l}\text { Type of } \\
\text { inversion }\end{array}$ & $\begin{array}{l}\text { Pulse/ } \\
\text { min }\end{array}$ & $\begin{array}{l}\text { Blood pressure } \\
\text { (mmHg) }\end{array}$ & $\begin{array}{l}\text { Place of } \\
\text { delivery }\end{array}$ & $\begin{array}{l}\text { Haemoglobin } \\
\text { grams \% }\end{array}$ & $\begin{array}{l}\text { Delivery } \\
\text { conducted by }\end{array}$ \\
\hline 20 & 1 & Vaginal & Complete & 110 & $90 / 70$ & PRH & 8.5 & Doctor \\
\hline 22 & 2 & Vaginal & Complete & 100 & $100 / 80$ & PRH & 9.2 & Doctor \\
\hline 23 & 1 & Vaginal & Complete & 130 & $80 / 50$ & PRH & 10.6 & Doctor \\
\hline 20 & 3 & LSCS & Partial & 96 & $110 / 70$ & PRH & 9.8 & Doctor \\
\hline 26 & 5 & Vaginal & Complete & 160 & 50-60 systolic & PHC & 3.2 & Nurse \\
\hline 28 & 3 & Vaginal & Complete & 146 & Un-recordable & $\mathrm{RH}$ & 3.8 & Nurse \\
\hline
\end{tabular}

The incidence of acute inversion of uterus was 0.22 per one thousand deliveries $(0.27$ per thousand vaginal deliveries and 0.11 per one thousand caesarean sections). Three cases were referred from outside hospital and three cases had delivered at Pravara Rural Hospital. Five cases had delivered vaginally, where as one case had undergone caesarean section. The age group of women ranged between 20-28 years with average age of 23 years.

The parity ranged between 1-5 with average of 2.5 children. The pulse rate of patients ranged between 96160 with average of 123 per minute. 
The blood pressure ranged between un-recordable blood pressure to $110 \mathrm{~mm} \mathrm{Hg}$ systolic and un-recordable to $80 \mathrm{~mm} \mathrm{Hg}$ diastolic. The average blood pressure was $70 \mathrm{~mm} \mathrm{Hg}$ systolic and $45 \mathrm{~mm} \mathrm{hg}$ diastolic. The haemoglobin at admission ranged between 3.2 grams percent to 10.6 grams percent. The mean haemoglobin of cases who had delivered at Pravara Rural Hospital was 9.5 grams percent, whereas the cases who were referred from outside had mean haemoglobin of 3.5 grams percent. All six cases were kept in Intensive care unit and two required intubation and ventilatory support.
The average blood units required for the 4 cases, who later survived were 1 unit of packed cell volume and 3 units of fresh frozen plasma, where as it was 5units of packed cell volume and 12 units of fresh frozen plasma, 6 units of platelets. There were two maternal deaths and four survivals among six cases of inversion of uterus. Severe anaemia, irreversible hypovolemic shock and multi-organ failure were causes of maternal deaths. The hospital stay of cases ranged between 1-10 days, with 8 days for those who survived and 1.5 days who died (Table 2).

Table 2: Management and outcome of cases.

\begin{tabular}{|c|c|c|c|c|c|}
\hline Treatment & $\begin{array}{l}\text { Blood and component } \\
\text { transfusion }\end{array}$ & $\begin{array}{l}\text { ICU } \\
\text { admission }\end{array}$ & Hospital stay & Any complication & Outcome \\
\hline $\begin{array}{l}\text { Manual reposition of } \\
\text { uterus under GA }\end{array}$ & $\begin{array}{l}1 \mathrm{PCV} \\
4 \mathrm{FFP}\end{array}$ & Yes & 7 days & Maternal anaemia & Survived \\
\hline $\begin{array}{l}\text { Manual reposition of } \\
\text { uterus under GA }\end{array}$ & $\begin{array}{l}1 \mathrm{PCV} \\
4 \mathrm{FFP}\end{array}$ & No & 8 days & Maternal anaemia & Survived \\
\hline $\begin{array}{l}\text { Manual reposition of } \\
\text { uterus under GA }\end{array}$ & $\begin{array}{l}1 \mathrm{PCV} \\
4 \mathrm{FFP}\end{array}$ & Yes & 7 days & Maternal anaemia & Survived \\
\hline $\begin{array}{l}\text { Manual reposition of } \\
\text { uterus under GA }\end{array}$ & $\begin{array}{l}1 \mathrm{PCV} \\
-\end{array}$ & Yes & 10 days & Maternal anaemia & Survived \\
\hline $\begin{array}{l}\text { Manual reposition and } \\
\text { Obstetric } \\
\text { hysterectomy }\end{array}$ & $\begin{array}{l}6 \mathrm{PCV} \\
15 \mathrm{FFP} \\
6 \mathrm{RDP} \\
3 \mathrm{SDP}\end{array}$ & Yes & 1 day & $\begin{array}{l}\text { Irreversible shock } \\
\text { DIC } \\
\text { Multi organ failure }\end{array}$ & Died \\
\hline $\begin{array}{l}\text { Manual reposition of } \\
\text { uterus }\end{array}$ & $\begin{array}{l}4 \mathrm{PCV} \\
8 \mathrm{FFP} \\
3 \mathrm{RDP}\end{array}$ & Yes & 2 days & $\begin{array}{l}\text { Irreversible shock } \\
\text { DIC } \\
\text { Multi organ failure }\end{array}$ & Died \\
\hline
\end{tabular}

\section{DISCUSSION}

Acute uterine inversion is a rare and life-threatening postpartum complication which mostly occurs, when the placenta fails to detach from the uterus after childbirth. There is cupping of the uterine fundus into the uterine cavity that may descend to the cervix (incomplete inversion) or beyond the cervix (complete inversion). Death may occur in $15 \%$ of the affected mothers due to pain, blood loss and shock. The shock is often described as being out of proportion to the bleeding. Uterine inversion is associated with multiparity, the use of oxytocin, macrosomia and fundal insertion of the placenta. Premature traction on the umbilical cord and fundal pressure before placental separation are the usual direct causes. $^{2}$ The key to a successful outcome is teamwork, as resuscitation and repositioning of the uterus are required to be done simultaneously. The quickest way to treat neurogenic shock, however, is to replace the uterus, which is best done manually, as delay can render replacement progressively more difficult and increase the risk of haemorrhage. ${ }^{13,14}$ In 1949,AB Johnson described the procedure commonly used for manual replacement of the uterus, now known as the Johnson manoeuvre. ${ }^{15}$ The chances of immediate repositioning are quoted as 43$88 \% .^{11,12,16}$ In Johnson's description the whole hand, plus two-thirds of the forearm, is placed in the vagina. Holding the fundus in the palm and keeping the tips of the fingers at the uterocervical junction, the fundus is raised above the level of the umbilicus. If the repositioning is attempted early, before oedema of the uterus and a contraction ring develops, the procedure is relatively easy to perform. As time is crucial, if manual replacement fails, performing the hydrostatic method in an operating theatre may be considered. Once uterine replacement is successful, the uterus should be held in place for a few minutes and oxitocics administered to promote contraction of the uterus and to prevent reinversion. ${ }^{17,18}$ Appropriate antibiotic cover is required to prevent infection. ${ }^{19}$ The placenta should only be removed after repositioning of the uterus and complete correction of the inversion in order to avoid shock and excessive bleeding. ${ }^{20}$ O'Sullivan published the first report of two cases describing hydrostatic replacement of the uterus following acute uterine inversion. ${ }^{21}$ Although authors have reported successful repositioning in individual case reports, a literature search failed to yield the success rate of the O'Sullivan technique. The World Health 
Organization recommends that if manual replacement fails, hydrostatic methods should be used. ${ }^{22}$ Before attempting this method, uterine rupture must be excluded. ${ }^{19}$ The procedure is performed in an operating theatre with the woman in the lithotomy position. Warm sterile water or isotonic sodium chloride solution is rapidly instilled into the vagina via a rubber tube or intravenous giving set, while the birth attendant's hand blocks the vaginal introitus. The fluid distends the vagina and pushes the fundus upwards into its natural position by hydrostatic pressure. The bag of fluid should be elevated approximately $100-150 \mathrm{~cm}$ above the level of the vagina to ensure sufficient pressure for insufflation. The problem with this method is the difficulty in maintaining a tight seal at the introitus. ${ }^{21}$ This can be overcome by the use of a silastic ventouse cup although a hand may still be necessary to ensure a tight seal. ${ }^{23}$ The literature gives little guidance regarding how to use the silicone cup. It is important not to seal the cup over the inverted fundus: instead, the cup should be positioned in the direction of the posterior fornix to allow vaginal distension. The possible complications associated with hydrostatic methods are: infection, failure of the procedure and, theoretically, saline embolus. ${ }^{24,19}$ Although as much as 5 litres has been recommended as the infusion volume, there have been no reported cases of saline embolus or pulmonary oedema. ${ }^{25}$ In the presence of a constriction ring, reposition of uterine inversion can be very difficult. Tocolysis has a role in relaxing the uterus before manual replacement or use of the hydrostatic method. The adverse effect of tocolyticmediated reduction in uterine tone, however, is an aggravation of postpartum haemorrhage, which is especially undesirable in the presence of shock. ${ }^{13,14}$ The rate of postpartum haemorrhage is quoted at $94 \%$, in the presence of acute inversion, the role of tocolysis becomes controversial. ${ }^{26}$ Many drugs have been tried to achieve tocolysis in acute inversion. These include: magnesium sulphate (4-6 g intravenously [IV] over 20 minutes), nitroglycerin (100 micrograms IV slowly, achieving uterine relaxation in 90 seconds when given sublingually) and terbutaline $\left(0.25 \mathrm{mg}\right.$ IV slowly). ${ }^{2,13,27,28}$

If manual replacement fails, general anaesthesia is required. The advantage of general anaesthesia is that, in addition to maternal pain relief, it promotes uterine relaxation. $^{25,12}$ In the past, the use of halothane inhalation was advocated because of its uterine relaxation properties. $^{29,30}$ With the availability of safer anaesthetic agents and the risk of severe hypotension with halothane, however, it is no longer preferred. Most of the cases of acute inversion of uterus can be managed without any surgical intervention. If there is delay in diagnosis, then the cases need one or other below mentioned surgical methods for reposition. There are two surgical procedures which are commonly practiced, Huntingdon's operation and Haultain's operation. In Huntingdon's operation, the abdomen is opened and the inversion site is exposed. A cupping is seen in the region of the cervix, with indrawn tubes and round ligaments. Two Allis forceps are introduced into the crater on each side and gentle upward traction is exerted on the forceps, with a further placement of forceps on the advancing fundus. By doing this, the uterus is pulled out of the constriction ring and restored to its normal position. ${ }^{31}$ In Haultain's operation, the cervical ring is incised posteriorly with a longitudinal incision. The rest of the steps are similar to Huntingdon's method. Once the uterus has been repositioned all incisions in the cervix, uterus and vagina are closed with interrupted sutures. Oxitocics are administered to maintain tone of the uterus. ${ }^{32}$

In the present series of six cases, four women survived, as three of them received prompt attention and one was brought to tertiary care hospital within one hour of occurrence. Two cases were brought after 2-3 hours of delivery in government hospitals. There was delay in recognition as well as transfer of the women to tertiary care hospital. Both the women were in severe haemorrhagic shock at the time of arrival to hospital emergency room. The haemoglobin had fallen to 3-4 grams indicating they had lost more than $2000 \mathrm{ml}$ blood. One of the cases was taken to operation theatre immediately and reposition was done by Haultains method. As there was severe uterine atony, abdominal hysterectomy was performed, and patient was kept in intensive care unit. Sufficient blood and blood products were transfused, but she could not be revived back from irreversible shock. Second case had delivered in government rural hospital and had complete inversion of uterus. Immediate reposition was tried but failed at the hospital. She had severe post-partum haemorrhage. She was shifted to tertiary care centre, but she had gone into severe haemorrhagic shock. Manual reposition was done in intensive care unit. Blood and blood products were administered, but she did not recover from the shock and died. Both the women, who later died, were delivered by nursing personnel at government hospitals. It was doubtful whether AMTSL was practiced at these hospitals or not. The placenta had delivered before the inversion occurred, ruling out possibility of adherent placenta in these two cases. There was one case of incomplete fundal inversion during caesarean section due to haste by junior obstetrician during placental removal. The condition was immediately identified, and uterus was reposited back to its normal position. Four women who survived following acute inversion, had normal postpartum course. They were given one or two units of blood and were discharged. These women were debriefed about the acute uterine inversion in them and were also informed that it may recur and, therefore, there is a need for hospital delivery and active management of the third stage of labour. They were reassured that fertility and reproductive outcome are not compromised following surgical correction. ${ }^{4,33}$

\section{CONCLUSION}

Acute inversion of uterus is a rare occurrence. Incidence is approximately 1:5000 deliveries. Prompt recognition of 
uterine inversion and its immediate reposition under anaesthesia was a key for saving lives. Delay in recognition and delay in transfer of cases resulted in haemorrhagic and neurogenic shock, causing death of a women. Institutional deliveries with practice of principles of active management of third stage of labour (AMTSL) and improvement in emergency obstetric care services at periphery, avoiding delays at all levels will help to reduce the incidence, morbidity and mortality associated with acute inversion of uterus.

\section{Funding: No funding sources}

Conflict of interest: None declared

Ethical approval: The study was approved by the Institutional Ethics Committee

\section{REFERENCES}

1. Bhalla R, Wuntakal R, Odejinmi F, Khan RU. Acute inversion of the uterus. Obstet Gynaecol. 2009;11:13-8.

2. Baskett TF. Acute uterine inversion: a review of 40 cases. J Obstet Gynaecol Can. 2002;24:953-6.

3. Calder AA. Emergencies in operative obstetrics. Baillieres Best Pract clin Obstet Gynaecol. 2000;14:4355 .

4. Mehra U, Ostapowicz F. Acute puerperal inversion of the uterus in a primpara. Obstet Gynecol. 1976;47:30S32S.

5. Das P. Inversion of the uterus. J Obstet Gynaecol Br Emp. 1940;47:525-48.

6. Mc Duff HC Jr, Keegan J. Postpartum inversion of unicornate uterus. Am J Obstet Gynecol. 1958;76:1299301.

7. Moir JC. Puerperal inversion of uterus. In: Munro Kerr's Operative Obstetrics. Bailliere, Tindall and Cox; 1964:575.

8. Catanzarite VA, Moffitt KD, Baker ML, Awadalla SG, Argubright KF, Perkins RP. New approaches to the management of acute puerperal uterine inversion. Obstet Gynecol. 1986;68 (Suppl 3):7-10.

9. Shah-Hosseini R, Evrard JR. Puerperal uterine inversion. Obstet Gynecol. 1989;73:567-70.

10. Brar HS, Greenspoon JS, Platt LD, Paul RH. Acute puerperal uterine inversion. New approaches to management. J Reprod Med. 1989;34:173-7.

11. Schaeffer G, Vesprosky EC. Inversion of the uterus. Surg Clinic North America. 1949;29:599-610.

12. Abouleish E, Ali V, Joumaa B, Lopez M, Gupta D. Anaesthetic management of acute puerperal uterine inversion. Br J Anaesth. 1995;75:486-7.

13. Vijayaraghavan R, Sujatha Y. Acute postpartum uterine inversion with haemorrhagic shock: laparoscopic reduction: a new method of management?. BJOG. 2006;113:1100-2.

14. O'Grady JP. Malposition of the uterus. Emedicine. Available at: www.emedicine.com/ med/topic3473.htm.

15. Johnson AB. A new concept in replacement of the inverted uterus and report of nine cases. Am J Obstet Gynecol. 1949;57:557-62.
16. Tank PD, Mayadeo NM, NandanwarYS. Pregnancy outcome after operative correction of puerperal uterine inversion. Arch Gynecol Obstet. 2004;269:214-6.

17. Catanzarite VA, Moffitt KD, Baker ML, Awadalla SG, Argubright KF, Perkins RP. New approaches to the management of acute puerperal inversion. Obstet Gynecol. 1986;68 (Suppl 3):7-10.

18. Samarrae K. Puerperal inversion of the uterus, with reference to pregnancy following Spinelli's operation. J Obstet Gynecol BrCommonw. 1965;72:426-9.

19. Thompson W, Harper MA. Post partum haemorrhage and abnormalities of the 3rd stage of labour. In: Chamberlain G, Steer PJ, eds. Turnbull's Obstetrics. $3^{\text {rd }}$ ed. Churchill Livingstone; 2002:622-623.

20. Kochenour NK. Intrapartum Obstetric emergencies. Crit Care Clin. 1991;7:851-64.

21. O'Sullivan J. Acute inversion of the uterus. BMJ. 1945;2:282-3.

22. World Health Organization. Correcting uterine inversion. Available at: www.who.int/reproductivehealth/impact/procedures/ correcting_p91_p94.html.

23. Ogueh O, Ayida G. Acute inversion: a new technique of hydrostatic replacement. $\mathrm{Br} \mathrm{J}$ Obstret Gynaecol. 1997;104:951-2.

24. Ward HR. O'Sullivan's hydrostatic reduction of an inverted uterus: sonar sequences recorded. Ultrasound Obstet Gynecol. 1998;12:283-6.

25. Paterson-Brown S. Obstetric emergencies. In: Edmonds DK, ed. Dewhurst's Textbook of Obstetrics and Gynaecology. $7^{\text {th }}$ ed. Oxford: Blackwell Scientific Publications; 2007:153.

26. Watson P, Besch N, Bowes WA Jr. Management of acute and subacute puerperal inversion of the uterus. Obstet Gynecol. 1980;55:12-6.

27. Dayan SS, Schwalbe SS. The use of small-dose intravenous nitroglycerin in a case of uterine inversion. Anesth Analg. 1996;82:1091-3.

28. Krenning RA, Dörr PJ, de Groot WH, de Goey WB. Non-puerperal uterine inversion. Case report. $\mathrm{Br} \mathrm{J}$ Obstet Gynaecol. 1982;89:247-9.

29. Beringer RM, Patteril M. Puerperal uterine inversion and shock. Br J Anaesth. 2004;92:439-41.

30. Soto RG, McCarthy J, Hoffman MS. Anaesthetic management of uterine inversion. J Gynecol Surg. 2002;18:165-6.

31. Huntington JL, Irving FC, Kellogg FS, Mass B. Abdominal reposition in acute inversion of the puerperal uterus. Am J Obstet Gynaecol. 1928;15:34-8.

32. Haultain FWN. The treatment of chronic uterine inversion by abdominal hysterectomy, with a successful case. Br Med J. 1901;2:974.

33. Thompson AJ, Greer IA. Non-haemorrhagic obstetric shock. Baillieres Best Pract Res Clin Obstet Gynaecol 2000;14:19-41.

Cite this article as: Bangal VB, Gagare SD, Bhardwaj S, Raut S. Study of incidence and outcome of acute inversion of uterus. Int J Reprod Contracept Obstet Gynecol 2018;7:5145-9. 